\title{
Cytogenetic study in acute myeloid leukaemia using peripheral blood samples sent by post
}

\author{
YS LI, FGJ HAYHOE \\ From the Department of Haematological Medicine, University Clinical School, Hills Road, Cambridge \\ $C B 22 Q L$
}

SUMMARY The patterns of chromosomal abnormalities in acute myeloid leukaemia (AML) revealed by study of peripheral blood specimens (group A) up to seven days old were comparable to the results from fresh bone marrow (group B). However, a decreasing proportion of cases providing enough metaphases for study, an increasing proportion of cases with chromosomal abnormalities, a decreasing ratio AN:AN + AA (see footnote Table 1) and a decreasing percentage of chromosomally normal cells in AN cases were found with ageing of specimens, which clearly demonstrates that cells with a normal karyotype were more likely to lose the capacity for dividing and die off than abnormal ones during ageing of specimens. Since the cells in older specimens were less active in division, a prolonged culture time was used. The different times for the cells from older specimens to re-enter active proliferation in culture conditions appeared to have some cytobiological significance. Three cases with $\mathrm{t}(8 \mathrm{q}-; 21 \mathrm{q}+)$ were present in group $\mathrm{A}$ but none in group B. Two cases of APL both showed a $t(15 q+; 17 q-)$ and the breakpoints seemed to be at 15q24 and 17q22. One case showed trisomy 8 and double minute chromosomes. The remission rate in AN patients was lower than in AA or NN patients.

Although fresh bone marrow is an ideal source of specimens for cytogenetic study in leukaemias, peripheral blood offers an alternative source, providing there is a substantial number of immature cells. In the last year or so, we have performed cytogenetic study in acute myeloid leukaemia (AML) using peripheral blood samples, which were aged up to seven days, as they were sent to us by post from all over Britain. In spite of the fact that some specimens contained few or no leukaemic cells, while in others many cells must have died during transit, we were still able to get enough metaphases for study in 47 of 93 cases. Well banded chromosomes were obtained in 35 cases. The patterns of chromosomal abnormalities were comparable to those found in fresh specimens taken from patients with AML admitted to our unit at Addenbrooke's Hospital, during the same period. The process of specimen ageing showed a selective killing between chromosomally normal and abnormal cells.

\section{Material and methods}

Ninety-three consecutive peripheral blood specimens (group A) taken from AML patients at diag-

Accepted for publication 23 December 1981 nosis and entry into the MRC 8th AML trial of therapy were received between May 1980 and May 1981. The specimens were from less than one day up to seven days, usually two to three days old, all having been sent by post. During almost the same period, namely, between April 1980 and May 1981, 29 fresh specimens (group B) from patients with AML admitted to Addenbrooke's Hospital were received. All the fresh specimens were of bone marrow except three of peripheral blood; four patients were in relapse, one in remission but three months before a relapse and the rest were all newly diagnosed. All patients presenting here had at least one cytogenetic study performed.

The cells were cultured at about $2 \times 10^{6} \mathrm{cells} / \mathrm{ml}$ of medium and $10 \mathrm{ml}$ of culture cell medium in a $20 \mathrm{ml}$ glass bottle without mitogen. Medium 199 was used for blood cells and McCoy's 5A medium with $15 \%$ fetal calf serum for bone marrow. The bone marrow cultures were harvested within $24 \mathrm{~h}$ but the blood cultures were harvested at 24,48 or $72 \mathrm{~h}$ usually. If the first harvest failed to get enough metaphases, the second and the third harvests followed in order to catch the first wave of cell division. To arrest metaphases 1-2 $\mu \mathrm{g}$ of colchicine were added 1-2 $\mathrm{h}$ before harvest.

The slides were prepared by a modification of the 
Table 1 Comparison of chromosomal patterns in successfully banded preparations between group $A$ and $B$

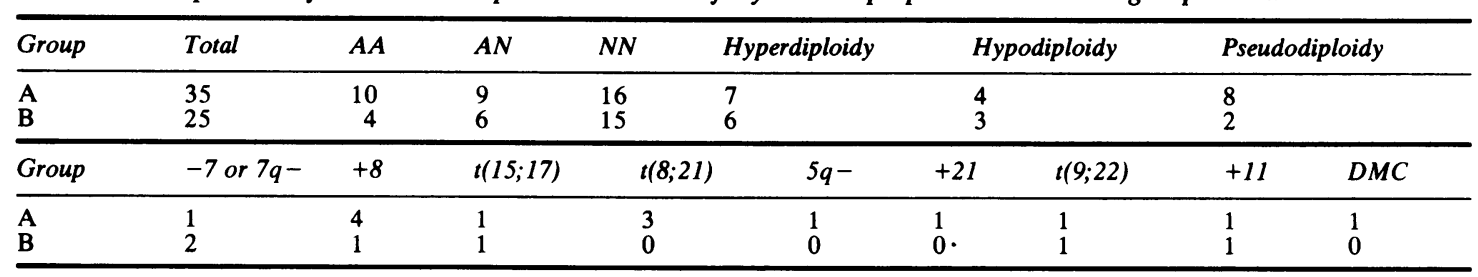

$\mathrm{AA}=$ cases with only abnormal clones; $\mathrm{AN}=$ cases with abnormal and normal clones; $\mathrm{NN}=$ cases with only normal clones; $\mathrm{DMC}=$ double minute chromosomes.

method of Moorhead et al ${ }^{1}$ and a modified G-banding method of Seabright ${ }^{2}$ was used. The chromosomes were identified according to the International System for Human Cytogenetic Nomenclature $^{3}$ and the karyotype was expressed as recommended under this system. The observation of at least two pseudodiploid or hyperdiploid cells or three hypodiploid cells showing the same abnormality was considered as an abnormal clone and only patients with such clones were classified as abnormal. If the number of metaphases which were analysable under the microscope was less than 5 per slide, this was regarded as not enough for study. At least 10 , but usually 20 or more metaphases were examined for each case.

All patients reported here were treated by a DAT regimen (daunorubicin, cytosine arabinoside and 6-thioguanine). All except one ${ }^{4}$ of the cases have not been published before.

\section{Results}

In the 93 cases of group A, enough metaphases for study were obtained in 47 cases (50.5\%). Banding study succeeded in 35 cases and revealed abnormal clones in 19 cases (54.3\%). Among the 29 cases of group B, 26 cases had enough metaphases (89.7\%), one case was poorly banded, and 10 cases showed abnormal clones $(40 \%)$. The patterns of chromosomal abnormalities of groups $\mathrm{A}$ and $\mathrm{B}$ were comparable as shown in Table 1.

In group $\mathrm{A}$, the ages of specimens were available in 85 cases; 42 cases $(49.4 \%)$ provided enough metaphases for study, and among the 30 well banded cases $15(50 \%)$ showed abnormal clones. To find out whether chromosomally normal or abnormal cells were more likely to die off during ageing of specimens the proportion of cases providing enough metaphases, the proportion of cases showing abnormal clones, the ratio AN:AN + AA (see footnote Table 1), the percentage of chromosomally normal cells in AN cases, and remission rates were measured and studied against ages of specimens, environmental temperature of transit (whether summer or winter) and culture time. The measure- ment of actual temperatures to which specimens were exposed during transit was not practicable, but specimens received during the period from May to September were separated as a "summer" group from a "winter" group received between October and April. The results are shown in Tables 2, 3, 4. Table 5 shows the remission rates of both groups $\mathrm{A}$ and $B$.

In group A leucocyte counts were available in 54 cases; the figures varied from 0.8 to 220 with average $37.8 \times 10^{9} / 1$ for cases without enough metaphases and from 1.3 to 86 with average $20.4 \times$ $10^{9} / 1$ for cases providing enough metaphases. The range of leucocyte counts in cases without enough metaphases is significantly wider than that in cases providing enough metaphases. The reason for this is that usually there were few or no immature cells when the leucocyte count was extremely low but cells were more likely to die off when the leucocyte count was extremely high.

The remission rate in group B shown in Table 5 refers to new patients only and excludes cases in relapse. The poor banding in some cases was due to accidental exposure of the slides to ultraviolet light, which made G-banding almost impossible. Counting chromosomes was still possible in poorly banded cases and revealed a normal modal number of chromosomes in 12 of the 13 cases. However, half (5 in 10) of the poorly banded cases had a fever $\left(>38^{\circ} \mathrm{C}\right)$ while nine of the remaining 40 cases had a fever.

Table 2 Specimen ages in relation to the other features (Group A)

\begin{tabular}{lccc}
\hline & $<1$ day & $2-3$ days & $4-7$ days \\
\hline Cases providing & $18 / 32$ & $14 / 29$ & $10 / 24$ \\
enough metaphases & $(56.3 \%)$ & $(48.3 \%)$ & $(41.7 \%)$ \\
Effectively banded cases & $6 / 14$ & $3 / 7$ & $6 / 9$ \\
showing abnormal clones & $(42.9 \%)$ & $(42.9 \%)$ & $(66.7 \%)$ \\
AN:AN + AA & $4: 6$ & $1: 3$ & $3: 6$ \\
Chromosomally normal & $(66.7 \%)$ & $(33.3 \%)$ & $(50 \%)$ \\
cells in AN cases (\%) & 33.3 & 52.2 & 10 \\
& 44.4 & & 10 \\
Mean (\%) & 70 & & 64.7 \\
\hline
\end{tabular}


Table 3 Comparison between winter and summer groups (group A)

\begin{tabular}{lll}
\hline Groups & Winter group & Summer group \\
\hline Cases providing & $32 / 55$ & $15 / 38$ \\
enough metaphases & $(58.2 \%)$ & $(39.5 \%)$ \\
Effectively banded cases & $11 / 22$ & $8 / 14$ \\
showing abnormal clones & $(50 \%)$ & $(57 \cdot 1 \%)$ \\
AN:AN + AA & $3: 11$ & $6: 8$ \\
& $(27.3 \%)$ & $(75 \%)$ \\
Chromosomally normal & 10 & 10 \\
cells in AN cases (\%) & 64.7 & 20 \\
& 80 & 33.3 \\
& & 44.4 \\
& & 52.2 \\
Mean (\%) & 51.6 & 38.3 \\
\hline
\end{tabular}

Table 4 Culture time in relation to other features (group A)

\begin{tabular}{|c|c|c|c|}
\hline Culture time (h) & $20-30$ & $30-50$ & $50-120$ \\
\hline $\begin{array}{l}\text { Harvests yielding } \\
\text { enough metaphases }\end{array}$ & $\begin{array}{c}6 / 32 \\
(18 \cdot 8 \%)\end{array}$ & $\begin{array}{l}27 / 46 \\
(58 \cdot 7 \%)\end{array}$ & $\begin{array}{l}16 / 27 \\
(59.3 \%)\end{array}$ \\
\hline $\begin{array}{l}\text { Cases showing abnormal } \\
\text { clones on banding }\end{array}$ & $\begin{array}{l}5 / 5 \\
(100 \%)\end{array}$ & $\begin{array}{l}10 / 20 \\
(50 \%)\end{array}$ & $\begin{array}{c}4 / 10 \\
(40 \%)\end{array}$ \\
\hline AN:AN + AA & $\begin{array}{c}2: 5 \\
(40 \%)\end{array}$ & $\begin{array}{r}4: 10 \\
(40 \%)\end{array}$ & $\begin{array}{c}2: 4 \\
(50 \%)\end{array}$ \\
\hline $\begin{array}{l}\text { Chromosomally normal } \\
\text { cells in AN cases }(\%)\end{array}$ & $\begin{array}{l}44 \cdot 4 \\
64.7\end{array}$ & $\begin{array}{l}10 \\
20 \\
52 \cdot 2 \\
70\end{array}$ & $\begin{array}{l}33 \cdot 3 \\
80\end{array}$ \\
\hline Mean $(\%)$ & $54 \cdot 5$ & $38 \cdot 1$ & $56 \cdot 7$ \\
\hline $\begin{array}{l}\text { Proportion of specimens } \\
\text { more than } 3 \text { days old }\end{array}$ & $\begin{array}{c}2 / 6 \\
(33 \cdot 3 \%)\end{array}$ & $\begin{array}{c}7 / 22 \\
(31 \cdot 8 \%)\end{array}$ & $\begin{array}{c}1 / 33 \\
(7.7 \%)\end{array}$ \\
\hline
\end{tabular}

\section{Discussion}

Most previous studies have suggested that in AML half the patients have an abnormal karyotype and half have a normal karyotype; both of them remain unchanged through the whole course of the disease, except that chromosomal evolution occurs in a small percentage of patients. Very recent work has thrown some doubt on these conclusions and suggested that most, if not all, patients with AML have chromosomal changes demonstrable if studied using cell culture for $24 \mathrm{~h}$, including a period of methotrexate cell synchronisation. ${ }^{56}$ Studies of clinical prognosis, cytomorphology and ultrastructure have revealed some differences between cases with dif- ferent cytogenetic findings, ${ }^{7-9}$ but cytobiological study in vitro has hardly been done. Although the number of cases in our study is relatively small, a surprising consistency from several aspects suggests certain conclusions.

As shown in Table 2 a decreasing proportion of cases with enough metaphases, an increasing proportion of cases with abnormal clones, a decreasing ratio AN: AN + AA and a decreasing percentage of chromosomally normal cells in AN cases were found during ageing of specimens. This strongly suggests that chromosomally abnormal cells survived better, and that chromosomally normal cells were more likely to lose the capacity for dividing and die off with ageing of specimens. This parallels behaviour sometimes observed during in vitro culture. ${ }^{10-12}$

The preferential death of cells with normal chromosomes during postal transit was more remarkable in the summer than in the winter as shown in Table 3. This is easy to understand if we suppose the main cause of cell death was cell starvation (shortage of nutrition and accumulation of metabolites). The only finding which is difficult to explain is that a lower ratio $\mathrm{AN}: \mathrm{AN}+\mathrm{AA}$ appeared in the winter group. The preferential death of chromosomally normal cells in originally AN cases might have turned some of them into AA cases in the winter whereas more extensive cell death in the summer, involving both normal and abnormal cells, may have led to an absence of metaphases at the time of study.

One could possibly argue that the absence of enough metaphases might have been caused by the lack of cell growth stimulators or the presence of inhibitors. In that case the regular changes of several parameters would be more difficult to explain; besides, dying or dead cells were often seen in our study. Of course loss of mitotic capacity may precede cell death.

An important difference in cytogenetic studies between using bone marrow and peripheral blood is that enough metaphases are usually directly present in bone marrow but not in blood. A short time of culture to stimulate cells to divide is often necessary. Moreover, cells stop dividing almost completely in aged specimens. Eight harvests of group A within a

Table 5 Remission rates in different groups

\begin{tabular}{|c|c|c|c|c|c|c|c|}
\hline \multirow[t]{2}{*}{ Groups } & \multirow[t]{2}{*}{ Total } & \multirow{2}{*}{$\begin{array}{l}\text { Cases without } \\
\text { enough } \\
\text { metaphases }\end{array}$} & \multirow{2}{*}{$\begin{array}{l}\text { Poorly banded } \\
\text { cases }\end{array}$} & \multicolumn{4}{|c|}{ Well banded cases } \\
\hline & & & & $A \boldsymbol{A}$ & $A N$ & $N N$ & $A N+A A$ \\
\hline $\begin{array}{l}\text { A } \\
\text { B (new patients } \\
\text { only) } \\
\text { Total }\end{array}$ & $\begin{array}{c}50 / 77 \\
(64.9 \%) \\
15 / 23 \\
(65.2 \%) \\
65 / 100 \\
(65 \%)\end{array}$ & $\begin{array}{c}27 / 40 \\
(67.5 \%) \\
2 / 3 \\
(66.7 \%) \\
29 / 43 \\
(67.4 \%)\end{array}$ & $\begin{array}{c}7 / 12 \\
(58 \cdot 3 \%) \\
1 / 1 \\
(100 \%) \\
8 / 13 \\
(61 \cdot 5 \%)\end{array}$ & $\begin{array}{c}4 / 6 \\
(66.7 \%) \\
3 / 4 \\
(75 \%) \\
7 / 10 \\
(70 \%)\end{array}$ & $\begin{array}{c}4 / 7 \\
(57 \cdot 1 \%) \\
2 / 5 \\
(40 \%) \\
6 / 12 \\
(50 \%)\end{array}$ & $\begin{array}{c}8 / 12 \\
(66.7 \%) \\
7 / 10 \\
(70 \%) \\
15 / 22 \\
(68.2 \%)\end{array}$ & $\begin{array}{c}8 / 13 \\
(61.5 \%) \\
5 / 9 \\
(55.6 \%) \\
13 / 22 \\
(59.1 \%)\end{array}$ \\
\hline
\end{tabular}


few hours of culture only revealed very occasional metaphases of poor quality. For specimens sent by post a somewhat longer time of culture thus appears to be mandatory. An asynchrony of onset of cell proliferation, and as long as four to five days of lag period before commencing proliferation were revealed by semisolid culture. ${ }^{13}$ Although our culture conditions were different, a prolonged culture time up to five days was used in this study and harvests were started between 24 and $48 \mathrm{~h}$ in order to catch the first wave of cell division. In our experience spontaneously transformed lymphocytes are usually too few to cause any confusion, and there is no doubt that metaphases studied by us represent immature myeloid cells or nucleated erythrocytes. All the three patients, whose cells were harvested between 80 and $120 \mathrm{~h}$ and showed a normal karyotype, achieved a complete remission. There is no doubt that the karyotypes revealed between 80 and $120 \mathrm{~h}$ of culture do represent the karyotypes of patients' leukaemic cells even though the karyotypes were normal. Moreover the appearance of mitoses in our study mainly represents the first wave of cell division, even though the culture time may be long.

A decreasing proportion of cases with chromosomal abnormalities was also found when the culture time was extended (Table 4), which might imply that chromosomally abnormal cells responded to the improvement of living conditions and re-entered into active proliferation quicker than normal ones. This is further confirmed by the observation that patients' cells which survived a longer time during ageing re-entered active proliferation sooner. However, this trend was observed only when specimens were more than two days old. This at least partly explains why a decreasing percentage of chromosomally normal cells in AN cases was observed with specimen ageing and with higher temperature but a decreasing trend was not found when culture time was extended. In one AN case of group A, cell culture was harvested twice, after one hour and after $24 \mathrm{~h}$, and showed enough metaphases for study on each occasion. A decreased percentage of diploid cells $(25 \% \rightarrow 9 \cdot 1 \%)$ was found at $24 \mathrm{~h}$ culture, which is consistent with the report by Carbonell et al. " On the other hand in two AN cases of group B, respectively four and five days old when received, an increased percentage of diploid cells $(0 \% \rightarrow 20 \%, 14.3 \% \rightarrow 60 \%)$ was found when culture time was extended. This may also suggest that chromosomally normal cells re-entered active proliferation later than abnormal ones. The underlying reason for the quicker re-entry into active proliferation of chromosomally abnormal cells is unknown.

Both the better survival and the quick re-entry into active proliferation shown by chromosomally abnormal cells supports the argument that chromosomally abnormal cells have a growth advantage in vitro over normal ones. This is consistent with the cytogenetic study of long term cultured leukaemic cell lines. The majority of such cell lines show very complex chromosomal abnormalities and dedifferentiation in cytomorphology and cytochemistry. ${ }^{14} 15$

A prerequisite in cytogenetic study using peripheral blood is the existence of a substantial number of immature cells in the blood. Golomb et $a l^{16}$ suggested that cytogenetic study can be performed successfully in patients with a leucocyte count higher than $15 \times 10 \% / 1$ and with about $10 \%$ immature myeloid cells. In our study, however, nearly half the cases (14 of 31 ) with enough metaphases had a leucocyte count lower than $5 \times$ $10^{9} / 1$. No obvious correlation was found between the frequency of chromosomal abnormalities and leucocyte counts. Thus, the lower limit of leucocyte count for successful cytogenetic study may be much below that suggested by Golomb et al. This is not surprising if we consider that chromosome preparations from stimulated lymphocytes can be made with samples of whole blood as small as 0.05 to $0.2 \mathrm{ml}$ for a microtechnique, ${ }^{7}$ while 10 to $20 \mathrm{ml}$ of blood were used in this study. The lowest blast cell count in cases with enough metaphases was $0.2 \times 10^{\%} / 1$ and only three of 18 cases without enough metaphases had a blast cell count lower than $0.2 \times 10^{9} / 1$. Clearly the main cause of failure to obtain mitosis in our study is cell death. No blasts are demonstrable by routine differential counting in $5 \%$ or even fewer patients with $A M L,{ }^{18}$ in whom cytogenetic study using peripheral blood may be really impossible.

Although ageing of specimens showed some selective killing as between chromosomally normal and abnormal cells, no obvious selective killing in cells with a specific chromosomal abnormality was observed. The patterns of chromosomal abnormalities in group A mainly represent the patterns in vivo.

Three cases of $\mathrm{t}(8 \mathrm{q}-; 21 \mathrm{q}+)$ made up a percentage of $5.1 \%$ in our 59 cases of AML. This is similar to the frequency reported by the First International Workshop on Chromosomes in Leukaemia, ${ }^{19} 12$ in 279 cases of ANLL (4.3\%) but much higher than the frequency $(1.5 \%)$ in London. ${ }^{20}$ This may suggest a geographic difference even within Britain. Two cases of acute promyelocytic leukaemia both showed a $\mathrm{t}\left(15 \mathrm{q}+; 17 \mathrm{q}^{-}\right)$and the breakpoints seemed to be at $15 q 24$ and $17 q 22$. The karyotype of the cases with DMCs is $46 \mathrm{Y} / 47 \mathrm{XY},+8$. Double minute chromosomes were present in both chromosomally normal and abnormal cells. The remission rate in the AN group patients was lower 
than in either AA or NN patients (Table 5). The number of patients studied is too small to justify any cogent speculation on this difference although it is different from common report.

A total of $40 \%$ of cases showing chromosomal abnormalities in group B, though lower than some reports, is not beyond expectation. The genesis of chromosomal anomalies in leukaemia might depend on the action of environmental factors against the genetic background of patients. Thus, the frequency and patterns of chromosomal anomalies in leukaemias vary within a wide range with changes of geography, nations, ${ }^{21}$ occupations, ${ }^{22}$ ages ${ }^{23}$ and study time. ${ }^{24}$ Apparently the depth and extent of the observers' search for chromosomal abnormalities and the observers' experience and skill also influence the frequency. Recently Lieber and Hsu reviewed a series of reports showing from 15 to $100 \%$ of patients with AML to have chromosomal abnormalities in different studies, and concluded that about $30 \%$ of patients show chromosomal abnormalities on average..$^{25}$ More recently Yunis et $a l$, based on studies with methotrexate cell synchronisation, suggested that all ANLL cases may have an abnormal karyotype. ${ }^{5}$ Clearly much more work has to be done before a final conclusion on this matter can be reached.

YS $\mathrm{Li}$ is the holder of a grant from the Chinese Academy of Medical Sciences and FGJ Hayhoe is Leukaemia Research Fund Professor of Haematological Medicine. We wish to thank Dr J Rees, Co-ordinator of the MRC 8th AML trial and numerous participating haematologists for supplying specimens and clinical data; Mr RJ Flemans for excellent technical assistance, and Mrs $J$ Chandler for help in preparation and typing of the manuscript.

\section{References}

' Moorhead PS, Nowell PC, Mellman WJ, Battips DM, Hungerford DA. Chromosome preparations of leukocytes cultured from human peripheral blood. Exp Cell Res 1960;20:613-6.

${ }^{2}$ Seabright M. A rapid banding technique for human chromosomes. Lancet 1971;ii:971-2.

${ }^{3}$ The Standing Committee on Human Cytogenetic Nomenclature. An international system for human cytogenetic nomenclature. Cytogenet Cell Genet 1978;21:313-404.

4 Li YS, Khalid G, Flemans RJ, Hayhoe FGJ. A case of acute myelomonocytic leukaemia with Philadelphia and small $F$ group chromosomes. Br J Haematol 1981;48:175-6. s Yunis JJ, Bloomfield CD, Ensrud K. All patients with acute non lymphocytic leukaemia may have a chromosomal defect. $N$. Engl J Med 1981;305:135-9.

- Rowley JD. Do all leukaemic cells have an abnormal karyotype? $N$ Engl J Med 1981;301:592-5.

' Sakurai M, Sandberg AA. Prognosis of acute myeloblastic leukaemia: chromosomal correlation. Blood 1973;41:93-104.

${ }^{8}$ Hogstedt B, Nilsson PG, Mitelman F. Micronuclei in erythropoietic bone marrow cells: relation to cytogenetic pattern and prognosis in acute non-lymphocytic leukaemia. Cancer Genet Cytogenet 1981;3:185-93.

'Ahearn MJ, Trujillo JM, Cork A, Fowler A, Hart JS. The association of nuclear blebs with aneuploidy in human acute leukaemia. Cancer Res 1974;34:2887-96.

${ }^{10}$ Carbonell F, Fleidner TM, Kratt E, Sauerwein K. Crecimiento de las cellulas leucemicas en cultivo: selection de clones citogeneticamente anormales. Sangre (Barc) 1979;24:105760.

" Carbonell F, Grilli G, Fliedner TM. Cytogenetic evidence for a clonal selection of leukemic cells in culture. Leukemia Res 1981;5:395-8.

${ }_{12}$ Berger R, Bernheim A, Flandrin G. Absence d'anomalie chromosomique et leucemie aigue; relations avec les cellules medullaires normales. CR Acad $\mathrm{Si}$ (D) (Paris) 1980;290:1557-9.

${ }^{13}$ Cronkite EP. Kinetics of granulocycytopoiesis. Clin Haematol 1979;8:351-70.

14 Koeffler HP, Golder DW. Human myeloid leukemia cell lines. Blood 1980;56:344-50.

is Karpas A. Human leukemia in vitro and the expressions of a new virus. In: Giraldo G, Beth E, eds. The role of viruses in human cancer I. New York: Elsevier-North Holland Inc, 1980.

${ }^{16}$ Golomb HM, Rowley JD. Significance of cytogenetic abnormalities in acute leukaemias. Hum Pathol 1981;12:515-22.

${ }^{17}$ Sandberg AA. Cytogenetic techniques in haematology. Clin Haematol 1980;9:19-38.

18 Wintrobe MM. Clinical hematology. Philadelphia: Lea \& Febiger, 1974:1482.

${ }^{19}$ First International Workshop on Chromosomes in Leukaemia. Chromosomes in acute non-lymphocytic leukaemia. $\mathrm{Br} J$ Haematol 1978;39:311-6.

${ }^{20}$. Lawler SD, Summersgill B, Clink HM, McElwain TJ. Cytogenetic follow-up study of acute non-lymphocytic leukaemia. Br J Haematol 1980;44:395-405.

${ }^{21}$ Second International Workshop on Chromosomes in Leukaemia. Belgium. October 2-6, 1979. Cancer Genet Cytogenet 1980;2:89-113.

${ }^{22}$ Mitelman F, Brandt L, Nilsson PG. Relation among occupational exposure to potential mutagenic/carcinogenic agents, clinical findings and bone marrow chromosomes in acute nonlymphocytic leukaemia. Blood 1978;52:1229-37.

${ }^{23}$ Nilsson PG, Brandt L, Mitelman F. Relation between age and chromosomal aberrations at diagnosis of adult nonlymphocytic leukemia. Leukemia Res 1977;1:385-6.

${ }^{24}$ Garson OM. Acute non-lymphocytic leukaemia. Clin Haematol 1980;9:39-54.

${ }^{25}$ Lieber E, Hsu YF. The cytogenetics of leukemia and some related disorders. In: Rubin AD, Waxman S, Gottlist AA, eds. The leukemia cell. Florida: CRC Press, 1979:44-9.

Requests for reprints to: Professor FGJ Hayhoe, Department of Haematological Medicine, University Clinical School, Hills Road, Cambridge, England. 